Funding: See page 260

Peer review: This article has been subject to a double blind peer review process

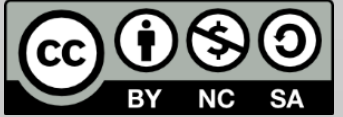

(C) Copyright: The Authors. This article is issued under the terms of the Creative Commons Attribution NonCommercial Share Alike License, which permits use and redistribution of the work provided that the original author and source are credited, the work is not used for commercial purposes and that any derivative works are made available under the same license terms.

\section{And So the Judge Returns: Blood Meridian Workshop at the University of Warwick}

\author{
Katja Laug*
}

Department of English and Comparative Literary Studies, University of Warwick *Correspondence: k.rebmann@warwick.ac.uk

\begin{abstract}
Pulitzer Prize winning author Cormac McCarthy's work has become required reading in literary criticism, and yet no syllabus appears to provision for the in-depth discussion his texts, particularly the 1985 novel, Blood Meridian: Or, the Evening Redness in the West, require. The 'And So the Judge Returns: Blood Meridian Workshop' at the University of Warwick emerged from the idea to provide a space that facilitates such a discussion. Designed to bring academics and non-academics of all ages together in one space, the workshop quickly developed from a small, Warwick-based event into a live-streamed and recorded international conference with a significant audience based in the United States.
\end{abstract}

The workshop reaffirmed the interest in the novel's enigmatic antagonist Judge Holden and motifs such as the landscape and violence. Less traditional ideas of the judge were also discussed, such as reading the judge as fraud or as weary of chaos and perpetual violence. The workshop succeeded in creating a space to share thoughts and ideas and continue the academic discourse on the novel. Speakers included Dr Nicholas Monk and Dr David Holloway, both established McCarthy critics; Peter Josyph whose artistic engagement with McCarthy's work and career his highly respected among critics; and Dr Dan O'Hara, expert in American Studies. Ronan Hatfull and Katja Laug represented the younger generation of McCarthy critics. Live-streaming also afforded insights into the academic discourse to the mostly non-academic online audience. The article provides a summary of the day's events and the links to the edited recordings.

Keywords: Cormac McCarthy, Blood Meridian, Judge Holden, workshop, live-stream, kid

Cormac McCarthy has been fascinating critics for more than five decades and has received considerable public attention since publishing The Border Trilogy in the 1990s. More recently, movie adaptions of No 
Country for Old Men and the Pulitzer Prize winning The Road have generated significant increase in public and academic interest and lead to a surge in McCarthy scholarship. Despite the peak of interest in McCarthy's most recent novels and their adaptations, the author's 1985 novel Blood Meridian remains at the centre of McCarthy criticism.

Approaches range from genre discussions, which generally view the novel as an anti-Western and critique of American mythology, to analyses of the central characters of the novel, the kid, and Judge Holden (Cant, 2008; Grammar, 1999; Kollin, 2001). The judge is at the centre of discussions of McCarthy's engagement with modernity; Vereen M. Bell and Nicholas Monk, for example, agree that Judge Holden represents the Enlightenment project pressed to its logical extreme (Bell, 1988; Monk, 2002; Monk, 2013). Additionally, the novel has frequently been examined in terms of its portrayal of landscapes and spaces as well as the scope of its representation of violence, often in historical connection to the American Westward Expansion (Jillett, 2016; Bourne, 2009;

Campbell, 2000; Eaton, 2003; Keller Estes, 2013).

Originally conceived as part of a larger research project, the 'And So the Judge Returns: Blood Meridian Workshop' generated significant interest not only at the University of Warwick, but among McCarthy aficionados globally. Particularly The Cormac McCarthy Society's interest and assistance in advertising the event made live-streaming a viable option. The University of Warwick has a history of making events like this workshop accessible through recording and live-streaming which facilitated changing the concept from a low-key internal event to a globally accessible international conference. Kindly sponsored by the Institute for Advanced Teaching and Learning, we succeeded in creating a physical and virtual space in which to share ideas and showcase a selection of the manifold approaches to McCarthy's enigmatic novel. While live-streaming tripled the numbers during the day, the subsequent availability of the unedited recordings reached a peak audience of between 215 and 430 views during 21 days after the workshop. The video recordings are now accessible through YouTube and the sound recording potentially on SoundCloud. Viewer numbers on these channels will be assessed in the future.

Opening the day with his workshop 'Becoming the Judge: A Practical Exploration of Judge Holden's Ideas'

(https://www.youtube.com/watch?v= 8WcXPpgedQ), Dr Nicholas Monk offered the opportunity for small groups to approach the novels inscrutable antagonist through a question-and-answer scheme. In a separate space and in groups of three the participants formulated two questions and nominated one 'judge' to answer these queries. In the carefully conceived and created centre space, a campfire setting with 
artificial fire and decorated with blankets and cushions, the group came together to share their ideas of Judge Holden's character. The nominated judges received a black hat and faced their questioners. The exercise showed four skilfully executed impressions of McCarthy's Judge Holden. The multifaceted portrayals highlighted the possibilities for a cryptic, pragmatic, sombre and solemn, honest, and fraudulent antagonist and challenged his relationship with the kid, questioned his sexuality, his position on power and choice, failure and the dance motif. The judge's looming presence and uncompromising position on violence and war generated questions about his motivation and ultimate aim in creating chaos as well as the true extent to which Judge Holden is in control of his own and his companions' actions. Interestingly, the question of the judge's relationship with the kid led two different groups to the conclusion that the judge appears to feel threatened by the kid which eventually leads to the kid's obliteration in the 'jakes' scene. Referring to the novels ending, questions about change - cultural and historical - and its effect on Judge Holden and his environment were raised and it was suggested that the judge might in fact be weary of the dance, of the violence that permeates the novel and is both exceptional and unexceptional in its intensity.

While the attending group engaged in Monk's workshop, the live audience expressed interest and surprise, stating that they had never understood the novel, and indeed the judge, in the way it was being discussed on site. A large percentage of the online audience consisted of non-academics, since the advertising support by the publishing house RandomHouse through social media generated significant interest especially in the US. Interestingly, this audience raised the question of the lack of a female judge despite several female attendants. This question mirrors the stark lack of female presence in McCarthy's texts and warrants further examination, albeit in a different format.

After a break the participants regrouped for Dr David Holloway's paper on 'Blood Meridian and the Right'

(https://www.youtube.com/watch?v=IZkBvPxm9Hw): 'What if Blood Meridian, for some readers, actually means what it says?' Quoting John Beck, Holloway explored the ways in which McCarthy's work in general, and Blood Meridian in particular, can be appropriated by the neoconservative right in the US, both at the time of publication during President Reagans second term of office and in the upsurge of neoconservative, right wing, post 9/11 discourse. Holloway highlighted the novels multidimensional narrative utilising film studies approaches and the idea that readers, not authors, create meaning. All readings, Holloway argued, are inflected and tainted by the readers own political, social, and historical context and therefore potentially open to an 
appropriation not only by a traditionally liberal position of the literary critic, but also by a conservative right wing. Juxtaposing the narrative with the discourse on war and violence, both during the post-Vietnam, end of Cold War era around the novels publication, and the war on terror post 9/11, Holloway posited that Blood Meridian and particularly Judge Holden's position can, if taken literally, feed into the neo-conservative agenda and what Raymond Williams calls the 'right wing sentiment'. Comparing the language and descriptions of violence and war in Blood Meridian with reports on the Atlacatal atrocities in El Salvador, Holloway showed the similarities not only in the detached intensity of style but also in acts of violence committed. While admitting to the speculative nature of his examination, Holloway provides plausible insights into the possibility of a neo-conservative appropriation of McCarthy's work and Blood Meridians potential to feed into conservative sensibilities of the American right wing.

While, as Holloway points out, a reading of McCarthy's texts through a neoconservative lens is not entirely original, it is nevertheless diametrically opposed to the generally liberal sentiments of McCarthy's academic audience and thus sheds light onto issues that may have previously been overlooked in McCarthy criticism. The author's notorious avoidance of public commentary as well as the substance of his work have rendered a firm situation of his political position impossible. Holloway had been specifically invited by the organiser to address these issues since this approach has great potential for discussion. The discussion time scheduled for Holloway's session had to be postponed and no specific reference to the paper was made during the round table session at the end of the day. However, Holloway's reading of McCarthy addressed increasingly urgent questions about the history and future of right-wing rhetoric in the United States.

In the ensuing panel, Katja Laug pointed out that McCarthy's characters are shallow, they lack interiority and their motivation and thought processes remain unknowable. In her paper "Everywhere the dying groaned and gibbered": Scars, Wounds, and Mutilation in Blood Meridian' (https://www.youtube.com/watch?v=Im WgnuJzOg) Laug suggested that McCarthy replaces interiority with exteriority and marks his characters' bodies to render them readable both for the audience and characters within the novel. Such markings on McCarthy's bodies appear in various forms, wounds and scars as the title suggests, but also ethnicity markers and tribal affiliation. The marauding Glanton Gang explicitly consists of individual characters only when accompanied from an internal perspective. Witnessing the gang from an external perspective, particularly during acts of violence and violation, they become 'spectre horsemen', an accumulation of scars, wounds, 
mutilations, and tattoos. Laug suggested that these bodily markings render recognisable affiliations which only terminate in death. Violence, she continued, marks its partisans as capable warriors and its scars evidence survival skills. In Blood Meridian especially, it remains unclear if Judge Holden or the kid should be read as protagonist since each is described in minute detail which, according to Laug, signifies importance and position within McCarthy's novels. In addition, Judge Holden is the novels only character that remains unscarred and unscathed which Laug linked to his role as avatar of space, a suggestion relating to her previous work on the enigmatic character of the judge.

Ronan Hatfull continued the panel with his paper 'Ruined Piece of Nature: Landscapes of Waste in King Lear, Blood Meridian and Mad Max: Fury Road' (https://www.youtube.com/watch?v=QE2cmVSgQ5k). He traced the wasteland scenery and abject violence of Shakespeare's King Lear through Jane Smiley's A Thousand Acres in which the land is likened with the female body, both ravaged by violence, to Blood Meridian. McCarthy not only quotes from Shakespeare's work directly but 'appropriates the violence... and lays it bare and unaccommodated,' as Hatfull suggested. The novel utilizes Shakespearean imagery when describing Judge Holden and the idiot, who is initially introduced as 'the fool', echoing the king and his fool in King Lear. Hatfull also pointed out that Holden's wanderings with the fool anticipate the father and son relationship in McCarthy's The Road. Stressing the cinematic success in portraying waste-scapes and violence in the 2015 movie Mad Max: Fury Road, Hatfull suggested that producer George Miller might be equipped to proceed with the long-expected movie adaptation of McCarthy's Blood Meridian.

Peter Josyph's 'Adventures in Reading Blood Meridian' offered a unique perspective on McCarthy's work and career. The artist, writer, producer, and long-time McCarthy aficionado joined the group via video conference and provided an informal dialogue in which he related his experience in reading Blood Meridian out loud to himself and how this changed his perspective and influenced his reading of the novel. Josyph's experience also highlighted the manifold approaches possible for McCarthy's work that also inform McCarthy criticism. The artist also recounted stories of interacting with McCarthy and the author's style of answering letters. While McCarthy is a recluse, he has only given three interviews during his extensive career, Josyph reflects that the author is very approachable privately but will not answer questions about his work as a writer. McCarthy's choice not to comment on his work and not to disclose information about his person or views leaves his work open for his audience to interpret, as suggested with respect to Holloway's talk. Following McCarthy's career from its earliest stages, Josyph related his 
encounters with McCarthy's work after his popular break through. A photograph Josyph took on Times Square advertising the adaptation of McCarthy's play The Sunset Limited has been used as cover of The Cormac McCarthy Journal Vol. 9 (2011) (https://journals.tdl.org/cormacmccarthy/index.php/cormacmccarthy/iss ue/view/363). Josyph's appearance delighted the workshop participants and his insights and experiences laid the foundation for the later round table discussion during which Josyph remained on conference call. While Josyph was intrigued by the idea of live-streaming the workshop, he asked that his talk not be streamed or recorded.

Dr Dan O'Hara (https://www.youtube.com/watch?v=j4vds5VGLZY) then introduced his reading by situating the novel at a time when there was a shift from concealed violence in the American South to unconcealed violence accompanying the Westward expansion. O'Hara discussed the icon of the cowboy that accompanies the myth of American violence as regenerative and holding identifiable American values that were retrospectively invented. The life of a cowboy, O'Hara suggested, was intensely uneventful and consisted mainly in a group of men herding cattle from one place to another, the reality of which is aptly portrayed in the 1972 movie Culpepper Cattle Company. Only in 1860 was the cowboy transformed into a folk hero of rugged individualism whose iconography is equated with freedom and is used in advertising and marketing to this day. The movie Culpepper Cattle Company and the novel Blood Meridian, O'Hara suggested, also share the basic plot of a tale of initiation of a young man who is both mediator of the new corporate landscape and the virgin lands that holds the myth of Manifest Destiny. As such the kid becomes an archetypical avenging angel who, despite being excluded from both the old and the new society, fights the one to protect the other. O'Hara also pointed out the holy war rhetoric that until today affects mainstream religious and political thought in US America and suggested that this is not germane only to Islam, but also to American religious rhetoric. This acuteness renders Blood Meridian 'a timely novel' that is both prophetic and proleptic, relevant not only at its time of publication but also in light of very recent events - the workshop took place only seven days after the Paris attacks on Friday 13 November 2015. O'Hara then proceeded to read from the end of the novel, specifically the final meeting between Judge Holden and the kid who has at this stage grown into a man.

The final gathering of the workshop was reserved for the Roundtable (https://www.youtube.com/watch?v=QBDDtPQyT0k) during which the day's topics could be discussed and questions raised. Leading into the roundtable with O'Hara's reading and referencing Josyph's earlier remarks, the group shared experiences of reading the novel aloud. 
$\mathrm{O}^{\prime} \mathrm{Hara}$ recounted the difficulty in finding the right emphasis for this reading and applying the same stress as when reading silently. The participants agreed that the novels rhetorical adeptness has its own physicality. The various experiences of reading the novel led to the question of who is in charge in Blood Meridian, the narrator, the reader, or Judge Holden. It became clear during the discussion that the focus remains on the enigmatic Judge Holden and his seductive rhetoric and all-encompassing violence. Peter Josyph posed the question of how Europeans view such violence, particularly in light of the recent terror attacks in Paris. Interestingly, the reply differed between male and female participants. Whereas Laug stated that to her this violence was still alien and rare on European soil, the male position was summarized by Nick Monk quoting McCarthy: 'young men love [war] and old men love it in them' (McCarthy, 2010: 262). It was proposed that in Blood Meridian's cosmos the only truth is violence and that McCarthy's novels articulate this truth. O'Hara stated that his impression is that if he understood the judge, he would be able to understand the violence in all of McCarthy's novels. Continuing from the question of violence in McCarthy's work, Josyph stressed the vast amount of research that has gone into writing the novel and how its descriptions echo with descriptions of war in novels such as Michael Herr's 1977 Vietnam novel Dispatches. The group continued the discussion leading on to the question of whether or not reading Blood Meridian should be enjoyable given the extremity of the violence it depicts. Holloway posited that violence in Blood Meridian is easier to read than, for example, in The Road. He suggested that Blood Meridian offers no interiority and its characters appear therefore unaffected by the violence. The enjoyment in reading the novel, all participants agreed, also derives from its beautiful and poetic language and complexity. James Christie then leads the discussion towards the often complex and awkward sexual undertones in the novel, asking why in the last scene two men would go to 'the jakes' together. Discussing the novels sexual undertones led the group back to Judge Holden and his paedophilic tendencies and the impression that he rejuvenates through murdering and violating children. This raised the question of what actually happens between the judge and the kid in the final scene in the jakes and the discussion ended on O'Hara's suggestion that the judge might be dead and the kid has become the judge. This last claim was met with enthusiastic approval by the online audience.

In the 'And So the Judge Returns: Blood Meridian Workshop', we successfully created an environment for all participants to share thoughts and ideas. Despite the success of the project and its relevance, both within a larger research project and in the field of McCarthy studies, 
some lessons can be learned for similar projects in the future. Stricter time keeping during the day would have provided room for more specific discussions after sessions. Furthermore, Monk's successful workshop suggests that creative sessions provide great potential for discussion and fruitful group work and should be included more in such events. Sharing the workshop through live-stream made academic work accessible to a non-academic audience and revealed the popular interest in both the author and the workings of academia on the subject. McCarthy's rich prose continues to fascinate academics and non-academics alike and the texts' subjects relate to acute and pressing social and political issues and highlight the importance and relevance of literature and art in contemporary society. The topics and discussions during the workshop have added to the discourse on McCarthy's work and have shown the authors relevance both within and outside academia.

\section{Acknowledgements}

I would like to thank the Institute for Advanced Teaching and Learning (IATL) at Warwick University for funding this project. Special thanks to IATL staff Nicholas Monk, Amy Clarke, Adam Cartwright, and Naomi de la Tour for their input during the organising process. The live-streaming and tech support was made possible by Luke Robert Mason, Ian O'Donoghue (Theatre Studies), and Roger Lindley (Audio Visual Services). For their assistance in advertising the event I am indebted to The Cormac McCarthy Society and RandomHouse. Thank you especially to Luke Robert Mason for his input in the live-streaming process and editing the videos and of course the speakers Nicholas Monk, David Holloway, Ronan Hatful, Peter Joseph, and Dan O'Hara.

\section{References}

Bell, V.M. (1988), The Achievement of Cormac McCarthy, Baton Rouge: Louisiana State University Press

Bourne, A. (2009), "'Plenty of signs and wonders to make a landscape": Space, Place, and Identity in Cormac McCarthy's Border Trilogy', Western American Literature, 44 (2), 108-125

Campbell, N. (2000), 'Liberty beyond its proper bounds: Cormac McCarthy's History of the West on Blood Meridian', in Wallach R., (ed.), Myth, Legend, Dust: Critical Responses to Cormac McCarthy, Manchester and New York: Manchester University Press and St. Martin's Press [distributor], pp. 217-26 
Cant, J. (2008), Cormac McCarthy and the Myth of American

Exceptionalism, New York: Routledge

Eaton, M.A. (2003), 'Dis(Re)Membered Bodies: Cormac McCarthy's Border Fiction', MFS: Modern Fiction Studies, 49(1), 155-80

Grammer, J.M. (1999), "'A Thing Against Which Time Will Not Prevail”: Pastoral and History in Cormac McCarthy's South', in Arnold, E.T. and Luce D.C. (eds.), Perspectives on Cormac McCarthy, Jackson: University Press of Mississippi, pp. 29-44

Jillett, L. (2016), Borders and Landscapes, London: Bloomsbury

Keller Estes, A. (2013), Cormac McCarthy and the Writing of American Space, Amsterdam and New York: Rodopi

Kollin, S. (2001) 'Genre and the Geographies of Violence: Cormac McCarthy and the Contemporary Western', Contemporary Literature, 42 (3), 557-588

McCarthy, C. (2010), Blood Meridian, or, The Evening Redness in the West, London: Picador

Monk, N. (2002), "'An Impulse to Action, an Undefined Want": Modernity, Flight, and Crisis in the Border Trilogy and Blood Meridian', in Hall, W.H. and Wallach, R. (eds.), Sacred Violence: Cormac McCarthy's Western Novels, El Paso: Texas Western Press/University of Texas at El Paso, pp. 83-103

Monk, N. (2013), 'News from Another World: Career and Critical Responses to Cormac McCarthy', Literature Compass, 10 (2), 111-121 Shaviro, S. (1999), "The Very Life of the Darkness": A Reading of Blood Meridian', in Arnold E.T and Luce D.C. (eds), Perspectives on Cormac McCarthy, Jackson: University Press of Mississippi, pp. 145-58

\section{To cite this article:}

Laug, K. (2016). And So the Judge Returns: Blood Meridian Workshop at the University of Warwick. Exchanges: The Warwick Research Journal, 3(2), 253261. Retrieved from:

http://exchanges.warwick.ac.uk/index.php/exchanges/article/view/99 